\title{
5. A passion for white elephants: some lessons from Australia's experience of nation building
}

\author{
Dr Richard Evans
}

\begin{abstract}
A 'white elephant' is a magnificent, high-status possession that is not particularly productive, costs a lot to maintain, and which you cannot get rid of. Since colonial times, Australians have had a weakness for white elephants. Traditionally, these were massive, debt-funded public works schemes that were economically, environmentally or socially dubious. In recent years, our white elephants have taken on different guises, but the ruinous expense and misdirected effort remain the same. This paper explores some of the reasons for our society's historic enthusiasm for white elephants, and suggests some remedies.
\end{abstract}

\section{Introduction}

In the dark days that followed the tragic and unnecessary death of Humpty Dumpty, a crisis meeting was held at the Royal Palace. Surrounded by his most senior counsellors, the King thumped the desk in exasperation. 'What this shows,' he thundered, 'is that I need more horses and more men!' This joke hinges on a remarkable aspect of human nature. We are smart creatures, and a vital aspect of human intelligence is the ability to learn from experience. But we also fail to learn from experience: as individuals, as communities, and as nations.

Perhaps the bleakest example of the human capacity to ignore the lessons of experience was provided by the Allied military command on the Western Front during World War I. The supreme commander of the British forces, Sir Douglas Haig, believed that to win the war the German army had to be defeated, and that the best way to achieve this was by massive frontal assault. He attempted this in 1916, with the Battle of the Somme. The British offensive was a disaster: they took 60,000 casualties, nearly 20,000 of them killed, on the first day. Undaunted, Haig pressed on with the assault for four months. In what remains the bloodiest battle in history, the British failed to reach the targets that had been set for the first day of the offensive. ${ }^{1}$

As winter closed in, making military operations impossible, there was much soul-searching in the British government. What should the war strategy be for 1917? Certainly, not another Somme. An amphibious landing to outflank the Germans? Helping the Italians to attack Austria? Or just holding the line and 
waiting for the USA to enter the war? ${ }^{2}$ Haig, however, had no doubts. He wrote in his diary that the solution was plain.

1. Send to France every possible man

2. ' ، ، ' aeroplane

3. '. ' ' gun. ${ }^{3}$

Here was the King, demanding more horses and more men. Haig got his way, and the result was ... another Somme. Though not as bloody as the previous year, the 1917 offensive similarly wrested a few miles of blasted quagmire from the German army at fearful cost in blood and treasure. Among the casualties were many thousands of young Australians.

\section{'A capacity for independent judgment'}

It is common for Australians to look back at World War I with pride and even some complacency. It was in the grim theatre of war that we first showed the world that we were different from the pompous, stupid, class-ridden English. The Diggers were first-rate soldiers, and their success was a reflection of the strengths of our national character.

In 1920, General Sir John Monash attempted to explain the remarkable fighting qualities of the men he had commanded:

The democratic institutions under which he was reared, the advanced system of education by which he was trained - teaching him to think for himself and to apply what he had been taught to practical ends [meant that] ... mentally the Australian soldier was well endowed. In him there was a curious blend of capacity for independent judgement with a readiness to submit to self-effacement in a common cause ... He was always mentally alert to adopt new ideas and often to invent them. ${ }^{4}$

It is hard for an Australian not to feel proud and pleased at such words, and there is no reason to doubt Monash's assessment of his soldiers. However, the ANZAC myth, this belief in our own innate independent thinking and clarity of judgement is, when applied to Australian society more widely, a delusion. Worse it is a particularly dangerous delusion. If we are a hardy, cheerful, laconic and adaptable people, always ahead of the game, we have no need to critically assess ourselves. The very suggestion is ridiculous.

We do have our weaknesses, our blind spots. Among them is a weakness for white elephants. 


\section{'The nineteenth century equivalent of city walls'}

The term 'white elephant' is one of those figures of speech which is almost always used by people unaware of its origins. It comes from a story told about the ancient Empire of Siam. There, albino elephants, because of their rarity and striking appearance, were considered sacred. They were symbols of the Emperor's power and semi-divine nature. One emperor devised an ingenious way to punish any courtier who annoyed him: he would present the man with one of the sacred imperial white elephants. The gift could not possibly be refused, nor could it be given to anyone else. And the Emperor knew that keeping the elephant in the magnificent style which custom demanded would financially ruin even the wealthiest of nobles. ${ }^{5}$ Thus a 'white elephant' is any magnificent, high-status possession that is not particularly productive, costs a lot to maintain, and which you cannot get rid of.

Since colonial times, Australians have been suckers for white elephants. We ran up massive debts to fund the construction of railways, dams and bridges, schemes that were often motivated more by status than economy. Edward Shann, best remembered for his classic economic history of Australia published in 1930, was scathing of this tendency. 'They were building,' he said, 'in haste and on credit, the nineteenth century equivalent of city walls. ${ }^{\prime} 6$

In 2007, I was commissioned to write the text of the book which would accompany the ABC TV documentary series Constructing Australia, which told the story of three great Australian engineering projects: the Sydney Harbour Bridge, the Kalgoorlie Pipeline, and the Overland Telegraph. ${ }^{7}$ Throughout, I tried to keep some perspective, and make the story more than a celebration of Aussie ingenuity. I emphasised, for example, that the Sydney Harbour Bridge was a genuinely debatable proposition.

To criticise the Bridge now seems like shooting Skippy: unthinkable, if not un-Australian. The Bridge is our most distinctive man-made icon, the centre-piece of many a fireworks display and Qantas advertisement. If the Bridge had not been built, it would have retarded the development of Sydney; and perhaps that would not be such a bad thing. Had the Bridge not been built, perhaps Sydney today would be a smaller and more liveable city. Maybe other capital cities and other centres in New South Wales would be larger, our economy, government and culture less centralised. It is, at least, a question worth raising.

Unfortunately, I did not have the space to express my reservations about the Australia's single most iconic symbol of nation building: the Snowy Mountain Scheme. 


\section{Australia's Great White Elephant}

The Great Depression put all thought of major capital works on hold in Australia for the best part of a decade, but even before the end of World War II, engineers and their political masters were again thinking big. The Snowy Mountain Scheme was one important result. Legislation for the project, which captured the water of the Snowy and Eucumbene rivers in massive dams and diverted it for electricity generation and irrigation, was passed in 1947. The project was not fully completed until 1974.

The Snowy was, no question, an epic engineering feat. Its combined storage capacity was equal to that of every dam and reservoir in Australia built before 1940: $160 \mathrm{~km}$ of tunnels and $130 \mathrm{~km}$ of aqueducts carried the water through a mountain range to the inland plains. The scheme became, and still is, an object of enormous national pride. It is somehow special, almost beyond criticism. ${ }^{8}$

But the Snowy is a white elephant - perhaps Australia's Great White Elephant. Economically, the scheme cannot be defended. As one analyst delicately put it:

The assessments made in this discussion have been economic and in their light the Snowy Scheme can hardly be regarded as a 'paying prosposition' ... The primary worth of the Snowy is psychological ... Australians ... have proved that they do not live by bread alone, although had they realised at the outset that the price of this loaf could be so high they may have hesitated before buying it. ${ }^{9}$

The scheme has also been an environmental disaster. Much of the irrigation water was used unwisely - not least because the cost was massively subsidised - resulting in salinity and land degradation. So much water was diverted, too, that the Snowy River itself was all but destroyed. ${ }^{10}$ And, as the governments of Australia, Victoria and New South Wales discovered in 2006 when they tried to flog it off, you can't even sell the bloody thing.

Australia is, as we all know, experiencing a catastrophic drought. It is not the worst ever in terms of rainfall and land area, but in terms of the numbers of people affected, it can perhaps be called the Great Drought. The water infrastructure of all our cities is under strain: the situation in many rural areas is disastrous. The issue of water, and how it should be managed, is a high national priority. In itself, this is a welcome development. But it is an indictment on our civic culture that the problem was allowed to become so serious.

\section{Disaster and social change}

Historically, Australian society has often faced up to important problems only when disaster - apocalyptic and undeniable disaster - forces us to face facts. I am currently seeking support for a history of the Black Friday bush fires of 1939. These fires were the most calamitous in the recorded history of Australia. More 
than $10 \%$ of the surface area of Victoria was burnt, scores of people were killed, and whole settlements reduced to ash, rubble and twisted metal. The disaster was of such magnitude that it forced Australian society - in rural areas, at any rate - to change its attitude to the natural environment and to fire, and to forge stronger and more civic-minded communities. ${ }^{11}$ It took the fall of Singapore to make us realise that we could no longer place our trust in the British Empire. It took the calamitous road toll of 1970 in Victoria - the total was over 1000 to change our attitudes to cars and how we use them. It took the AWB bribery scandal to make us realise the truth of an Adam Smith truism: that a privatised monopoly is the one thing worse than a state monopoly. There are many other examples.

That disaster should act as an agent of change is not surprising - but really it should not require disaster, not when we pride ourselves on our clear-eyed realism, and when there is plenty of warning. That Australia would face a water crisis in the early years of the twenty-first century was predictable - and was predicted. In 1968, C.H. Munro, a professor of civil engineering at the University of New South Wales, gave a public lecture on Australia's water future. Munro was scathing of our culture of waste, of how in our large cities 'the use of water for roses and lawns and car washing are taken for granted as essential human needs' ${ }^{12}$ He was thinking long-term, and saw trouble ahead:

Planning authorities contemplate a population of five million people in Sydney by the year 2000. To some this is a horrible thought. Certainly it poses many problems to the engineer and town planner in regard to transport ... provision of water supply and sewerage and the like. ${ }^{13}$

We can't say that we were not warned; we just didn't listen.

In 1966, as a severe drought affected much of New South Wales and Queensland, a senior agricultural economist wrote:

Government policies ... and skewed values which allow us to regard the failure of an electrical retailer as divine retribution but the bankruptcy of an under-capitalised and inefficient farmer as a blot on the social escutcheon, may well cause the cost of [future] droughts to be avoidably high.

There is need for farmers and governments to confer in evaluating the lessons of past droughts and in planning for the future. All proposals, particularly those with a strong political bias such as for widespread irrigation development, should be judged by business criteria [and] ... in terms of ... the population generally, which has, in the end, to bear the cost. ${ }^{14}$

We can't say that we were not warned; we just didn't listen. 


\section{New white elephants}

J.J.C. Bradfield, the driving force behind the creation of the Sydney Harbour Bridge and a prophet of diverting rivers to irrigate the Australian desert, was fond of quoting the great American engineer Daniel Burnham: 'Make Big Plans, for little plans have no magic to stir men's blood.' ${ }^{15}$ Restoring damaged land and river systems, devising ways to make the water we have go further, managing our farmland, forests, cities and towns more efficiently and intelligently: these are projects which do not stir the blood. But that does not make them any the less important.

Certainly they are more important, more worthy of money, resources, discussion and effort than what has replaced dams, bridges and pipelines as the white elephants of our age. I am referring to the Major Event. I come from Melbourne, and in 2006 we hosted the Commonwealth Games. This privilege was secured after the only other city willing to do the job withdrew its bid. And so, at vast expense - how vast is hard to say because all the figures are very woolly, but their very wooliness suggests that it was a lot - Melbourne staged a largely meaningless sporting event organised around a largely meaningless group of countries. It was strange living through it - for months it seemed that some sort of cosmic mother-in-law was coming to visit, and that she mustn't see that the bedroom was untidy or the renovations were unfinished, and we simply must install a new patio, even though we can't afford it.

We do a lot of this sort of thing in Melbourne: the FINA World Swimming Championships of 2006 springs to mind, as does the Fl Grand Prix. Now there is bizarre event. It is the twenty-first century equivalent of a medieval tourney: a stupendous display of conspicuous and pointless consumption. It is Austin Powers-land, defiantly politically incorrect, complete with leggy pit girls and tobacco ads. It is worth visiting, once, to experience the roar and the smell, as someone once described it, of burning money. And yet this vast travelling festival global capital runs at a dreadful loss. Year after year, the circus flies in, loses money - our money, much if it - and then leaves.

The economic justification for Major Events is revealingly vague. There is talk of visitor numbers, turnover generated, money spent in secondary areas, growing the brand (Melbourne is a brand, apparently). It is much like the Snowy. If you point out that the power that is generated is too expensive, then you are told that it also provides irrigation water. If you argue that the water has been wasted, grossly subsidised, and that we have no business growing rice in Australia, then you are told that the same water generates power. And that anyway, there are flow-on benefits, and the whole thing was inspiring and made people proud, and that only mean-spirited bean counter of questionable patriotism would look too closely at the bottom line. 
The nation-building challenges that face us now are not glamorous. They are to adapt our ways of living, working and travelling to the realities of the land that we inhabit. Among other things, this involves fostering some of the qualities which John Monash identified in the Australian soldier of 90 years ago: a high-quality education; an openness to new ideas; an independent but unselfish cast of mind; and — crucially — involvement with the institutions of civil society.

As an historian, I read a lot of old newspapers. Something which often strikes me is how many clubs and committees and associations there used to be, and how actively involved ordinary people were in the affairs of unions, political parties, local councils, churches, debating societies, and much else. Some people still do all these things, of course, but they are a small minority now: it used to be the common thing. Some of these civic groups achieved great things, such as female suffrage. Others did no more than run a tennis competition. And there were groups that were pernicious: dedicated to fostering racial and sectarian prejudice, for example. For all that, there was and still is value, in and of itself, in such civic participation.

Our political culture is becoming dangerously distanced from ordinary people. Our political parties are machines of power. Their membership bases are tiny, and democracy at branch level is a sober farce. At the same time, governments are increasingly interventionist, centralist and disdainful of due process. The recent change of federal government offers hope for reform, if only on the premise that a change is as good as a holiday. But it does concern me that the Rudd administration shows some of the managerialist, reflexively authoritarian tendencies that marked its predecessor.

If there is a weakness in our nation that needs repair, needs building, it is in the institutions of civic society, in empowering and encouraging participation. The process of decision-making may take longer. Internal dissent and discussion others may frustrate or embarrass those in executive authority. But if nothing else it might prove a protection against our weakness for white elephants.

\section{ENDNOTES}

1 Lynne McDonald, Somme, Michael Joseph, London, 1983.

2 Leon Wolff, In Flanders Fields: The 1917 campaign, (1958) Penguin, London, 2001.

3 Ibid, p.105.

4 General Sir John Monash, The Australian Victories in France in 1918, Lothian, Melbourne, 1920, p. 314.

5 OED, lst ed., vol III, p.85.

6 E.O.G. Shann, An Economic History of Australia, Cambridge University Press, Cambridge, 1930, p. 126.

7 Richard Evans and Alex West, Constructing Australia, Miegunyah Press, Melbourne, 2007.

8 Current Affairs Bulletin, 'Murrumbidgee irrigation: A regional study', vol. 31, no. 10, 1 April 1963.

9 Current Affairs Bulletin, 'The Snowy: An appraisal', vol. 31, no. 13, 13 May1963, pp. 207-8. 


\section{Australia Under Construction}

10 Tim Flannery, 'Beautiful lies', Quarterly Essay, no. 9, 2003.

11 Tom Griffiths, Forests of Ash, Cambridge University Press, Cambridge, 2001.

12 C.H. Munro, The Future Conservation of Australia's Water Resources, University of Sydney, Sydney, 1969 , p. 11.

13 Ibid, p. 28

14 Current Affairs Bulletin, 'Drought', vol. 38, no. 4, 11 July 1966, p. 64.

${ }^{15}$ Richard Raxworthy, The Unreasonable Man: The life and works of J.J.C. Bradfield, Hale and Iremonger, Sydney, 1989, p. 94. 